\title{
Refractory Brain Neoplasm
}

National Cancer Institute

\section{Source}

National Cancer Institute. Refractory Brain Neoplasm. NCI Thesaurus. Code C71702.

Brain neoplasm resistant to treatment. 